\title{
The Influence of Learning Motivation and Emotional Intellegence on Student Achievement at SMA Negeri 1 Semendawai Barat OKU Timur
}

\author{
Noviyanti $^{1 *}$, Bukman Lian ${ }^{1}$, Alhadi Yan Putra ${ }^{1}$ \\ ${ }^{1}$ Universitas PGRI Palembang, Indonesia \\ ${ }^{*}$ Corresponding author. Email: novinadiva01@gmail.com
}

\begin{abstract}
The aim of this study is to evaluate the positive effect of learning motivation on student achievement, the positive effect of emotional intelligence on student achievement, and the positive effect of learning motivation and emotional intelligence on student achievement. This study was carried out at SMA Negeri 1 Semendawai Barat OKU Timur. This study employs a descriptive method in conjunction with a quantitative approach. The following data testing techniques were used in the study: multicollinearity test, heteroscedasticity test, multiple linear regression analysis, partial test, and simultaneous test using the SPSS software version 20. According to the findings of this report, 1) there is a 10\% positive effect of learning motivation on learning achievement. 2) Emotional intelligence has a 39.1\% positive impact on student achievement. 3) There is a 568 percent positive effect between learning motivation and emotional intelligence on learning achievement. With the inference that learning motivation and emotional intelligence have an impact on student achievement in SMA Negeri 1 Semendawai Barat OKU Timur.
\end{abstract}

Keywords: Learning Motivation, Emotional Intellegence, Student Achievement

\section{INTRODUCTION}

Learning achievement is the product of impressions that result in improvements in a person as a result of learning activities he has engaged in [1]. Learning achievement as an assessment of the results of learning activities which are expressed in numbers, letters, and sentences which can reflect the results achieved by each child in a certain period [2]. Sardiman [3] states that one of the successes in education is learning achievement. the results (mastery) achieved by students in certain fields of study after participating in the teaching and learning process. The changes that are obtained are not only knowledge but also skills or abilities in certain fields or subjects. Student learning achievement cannot be distinguished from learning activities because learning is a process, while learning achievement is the end result of the learning process. For a student, studying is a duty that must be fulfilled in order to expand the student's awareness. As a result, it will be useful and helpful to people now and in the future. A student's educational achievement or failure is determined by the learning process that the student personally experiences.

According to Majid [4] motivation as a driving force for individual activities to take an action to achieve certain goals. Motivation may also be described as a driving force or a strategy for achieving success and avoiding failure. Motivation in learning is the psychological driving force within a student to expand understanding, knowledge and skills in learning. Apart from motivation, another thing that can improve student achievement is emotional intelligence (EQ). Learning motivation according to Widiarti [5] can be interpreted as guidance and direction for behavior which includes needs, interests, attitudes, values, aspirations and stimulants.

Emotional intelligence, according to Daud [6], is a person's capacity to handle his emotional life with intelligence (to manage our emotional lives with intelligence); preserving equilibrium of emotions and their expressions (the appropriateness of emotion and its expression) through self-awareness skills, self-control, self-motivation, and empathy. Dimyati \& Mudjiono [7] suggests that emotional intelligence requires sensitivity to feel, to learn to acknowledge, appreciate feelings for oneself and others and respond appropriately, then apply them effectively in everyday life. Emotional intelligence is highly affected by its surroundings, is not constant, and can alter at any time. As a result, the role of the environment, especially parents, in childhood has a significant impact on the development of emotional intelligence. EQ skills are not diametrically opposed to IQ or cognitive skills; rather, they communicate creatively, both conceptually and in the real world. Furthermore, EQ is less affected by heredity. 
It also claims that intellectual intelligence (IQ) only accounts for $20 \%$ of a person's performance, with the remaining $80 \%$ attributed to other factors such as emotional intelligence (EQ), or the ability to motivate oneself, resolve anger, and manage pressure [8]. Mood, mood setting, empathy, and the ability to collaborate These two intelligences are critical in the learning process. IQ cannot act properly in the absence of emotional appreciation for the subjects taught in school. However, these two intelligences generally complement each other in a balanced manner. The keys to effective student learning in school are IQ and EQ.

For most people, emotional intelligence (EQ) is more important than intellectual intelligence (IQ) in achieving success and achievement. Because by having emotional intelligence, people can empathize or understand the feelings of others, establish good communication and relationships, negotiate, and cooperate with others well. This can be interpreted that emotional intelligence has an important control for emotional regulation so that it becomes stable, especially when students are in the teaching and learning process and face lessons that they consider difficult.

Based on the facts that occurred in the field, the majority of students at SMA Negeri 1 Semendawai Barat OKU Timur had low learning motivation. Likewise, the management of emotional intelligence is not good enough. This can be seen during the teaching and learning process and when activities are carried out outside of learning hours. There are still many students who are not able to motivate themselves to stay focused on learning. They tend to be frustrated, have difficulty controlling emotions and lack self-confidence when facing difficulties, be it problems with learning or problems with friends.

Based on the above, the researcher attempts to perform research in order to learn more about the impact of learning motivation and emotional intelligence on student achievement. As a result, the researcher devised a study called "The Impact of Learning Motivation and Emotional Intelligence on Student Achievement in SMA Negeri 1 Semendawai Barat OKU Timur".

\section{METHODS}

A research method is a scientific method used to collect objective, accurate, and reliable data with the aim of advancing, proving, and developing information that can be used to understand, solve, and predict problems [9].

This thesis employs a quantitative research approach with inferential analysis of the causality relationship, which seeks to determine the effect of the independent variable on the dependent variable. This is done to see whether learning motivation and emotional intelligence have any impact on student performance, either concurrently or partially. After that, the results of research on this effect will be obtained in general.

According to Sugiyono [9] population is a general area consisting of objects / subjects that have certain quantities and characteristics that are determined to be researched and conclusions drawn. The population in this study were all students of SMA Negeri 1 Semendawai Barat class XI IPA 1 to XI IPA 3, with a total population of 108 students from the three science classes.

The sample is a subset of the population in terms of size and composition. Since the total population is known, the number of samples taken is determined using the Yamane formula with a sampling error of $10 \%$ [9].

Documentation and questionnaires were used to collect data in this report. A questionnaire was used as a research tool to collect analytical data on the observed variables.

\section{RESULTS AND DISCUSSION}

\section{Testing $X_{1}$ (Learning Motivation) and $X_{2}$ (Emotional Intelligence) on $Y$ (Learning Achievement) partially (t test)}

The statistical $\mathrm{t}$ test effectively demonstrates how much one explanatory variable or independent variable can explain the variance of the dependent variable on its own [10]. If the degree of significance is less than 5\%, $\mathrm{HO}$ is rejected and $\mathrm{H}$ is accepted, indicating that the independent variable will clarify the dependent variable. If the significance level is greater than $5 \%$, then $\mathrm{H}_{0}$ is accepted and $\mathrm{H}$ is refused, implying that the independent variable cannot be clarified individually.

Coefficients $^{\mathrm{a}}$

\begin{tabular}{|c|c|c|c|c|c|c|c|}
\hline \multirow[t]{2}{*}{ Model } & \multicolumn{2}{|c|}{ Unstandardized Coefficients } & \multirow{2}{*}{$\begin{array}{c}\text { Standardized Coefficients } \\
\text { Beta }\end{array}$} & \multirow[t]{2}{*}{$\mathrm{t}$} & \multirow[t]{2}{*}{ Sig. } & \multicolumn{2}{|c|}{ Collinearity Statistics } \\
\hline & B & Std. Error & & & & Tolerance & VIF \\
\hline (Constant) & 60.727 & 4.356 & & 13.941 & .000 & & \\
\hline MB & .120 & .049 & .226 & 2.446 & .016 & .970 & 1.031 \\
\hline KE & .129 & .048 & .246 & 2.662 & .009 & .970 & 1.031 \\
\hline
\end{tabular}

From table 4.1 above, column $\mathrm{X}_{1}$ (Learning Motivation / MB) explains if $t$ count (2.446)> $t$ table (1.98) so the zero hypothesis is rejected. The conclusion is that learning motivation has an effect on learning achievement. Column $\mathrm{X}_{2}$ (Emotional Intelligence / KE) shows if $t$ count $(2,662)>t$ table (1.98) so the zero 
hypothesis is rejected. The conclusion is that Emotional Intelligence affects learning achievement.

\begin{tabular}{|c|c|c|c|}
\hline \multicolumn{4}{|c|}{$\begin{array}{c}\text { Table } 2 . \\
\text { Coefficients }^{\mathrm{a}}\end{array}$} \\
\hline & \multicolumn{3}{|c|}{ Correlations } \\
\hline Model & Zero-order & Partial & Part \\
\hline $1 \mathrm{MB}$ & .550 & .327 & .225 \\
\hline $\mathrm{KE}$ & .725 & .626 & .523 \\
\hline
\end{tabular}

a. Dependent Variable: PB

Table 2. shows the partial termination coefficient for the Learning Motivation variable of 0.327 . This value is then squared and proxied to $((0.3272) \times 100 \%))=10.6 \%$ of learning achievement. As for the Emotional Intelligence variable of 0.626 , the value is then squared and proxied to $((0.6262) \times 100 \%))=39.1 \%$. So, it can be seen that separately Emotional Intelligence has an effect of $39.1 \%$ on the learning achievement of class XI IPA students at SMA Negeri 1 Semendawai Barat.

2. Testing $X_{1}$ (Learning Motivation) and $\mathbf{X}_{2}$ (Emotional Intelligence) against $\mathrm{Y}$ (Learning Achievement) simultaneously (F test).

\begin{tabular}{|c|c|c|c|c|c|}
\hline \multicolumn{6}{|c|}{$\begin{array}{c}\text { Table } 3 . \\
\text { ANOVA }^{\mathrm{b}}\end{array}$} \\
\hline Model & Sum of Squares & Df & Mean Square & $\mathrm{F}$ & Sig. \\
\hline 1 Regression & 92.940 & 2 & 46.4707 & 7.907 & $.001^{\mathrm{a}}$ \\
\hline Residual & 617.060 & 105 & 5.877 & & \\
\hline Total & 710.000 & 107 & & & \\
\hline \multicolumn{6}{|c|}{ a. Predictors: (Constant), KE, MB } \\
\hline b. Dependent & ariable: PB & & & & \\
\hline
\end{tabular}

The $\mathrm{F}$ test is used to assess how much Learning Motivation $\left(\mathrm{X}_{1}\right)$ and Emotional Intelligence $\left(\mathrm{X}_{2}\right)$ influence learning achievement (Y). If the degree of significance (productivity) is less than $5 \%, \mathrm{H} 0$ is rejected, indicating that the independent variables should explain the dependent variable simultaneously or jointly. In contrast, if the significance amount is greater than $5 \%, \mathrm{H}_{0}$ is tolerated, indicating that the independent variables are unable to describe the dependent variable together. The following table summarizes the findings of a statistical study of data using SPSS:

If $\mathrm{F}$ count $(7,907)>\mathrm{F}$ table $(3,04), \mathrm{H} 0$ is rejected, as seen in table 4.3 above. This implies that both learning motivation and emotional intelligence have an effect on learning achievement.

\begin{tabular}{|c|c|c|c|c|c|}
\hline \multicolumn{6}{|c|}{ Model Summary $^{\mathbf{b}}$} \\
\hline Model & $\mathrm{R}$ & R Square & Adjusted R Square & Std. Error of the Estimate & Durbin-Watson \\
\hline 1 & $.759^{a}$ & .576 & .568 & 1.693 & 2.275 \\
\hline \multicolumn{6}{|c|}{ a. Predictors: (Constant), KE, MB } \\
\hline \multicolumn{6}{|c|}{ b. Dependent Variable: PB } \\
\hline
\end{tabular}

Given that the R2 value is 0.568 and the multiple correlation value varies between 0.49 and 0.599 in the table above, it can be inferred that there is a moderate association between learning motivation and emotional intelligence on learning achievement. This demonstrates that the percentage of the impact of the independent variables (Learning Motivation and Emotional Intelligence) on the dependent variable (Learning Achievement) is 56.8 percent, or that the variance of the independent variables used in the model will explain 56.8 percent of the dependent variable. Other factors not included in this research model affect or justify the remaining 43.2 percent. As a result, the higher the Learning Motivation and Emotional Intelligence, the higher the Learning Achievement; conversely, if the Learning Motivation and Emotional Intelligence are low, the Learning Achievement would be low as well. 


\section{CONCLUSION}

Based on the findings of descriptive study and data interpretation, and hypothesis testing, the following conclusions can be drawn: 1) based on the partial test, the partial determination coefficient value for the Learning Motivation variable is 0.327 . This value is then squared and proxied to $((0.3272) \times 100 \%))=10.6 \%$ of learning achievement. As for the Emotional Intelligence variable of 0.626 , this value is then squared and proxied to $(0.6262) \times 100 \%))=39.1 \%$. So, it can be seen that separately Emotional Intelligence has an effect of $39.1 \%$ on the learning achievement of class XI IPA students at SMA Negeri 1 Semendawai Barat, and 2) based on the simultaneous testing, the $R_{2}$ number is 0.568 and the multiple correlation value is between $0.49-0.599$, it is possible to assume that there is a mild association between learning motivation and emotional intelligence and academic achievement. This demonstrates that the percentage of the impact of the independent variables (Learning Motivation and Emotional Intelligence) on the dependent variable (Learning Achievement) is 56.8 percent, or that the variance of the independent variables used in the model will explain 56.8 percent of the dependent variable. Other factors not included in this research model affect or justify the remaining 43.2 percent.

\section{ACKNOWLEDGMENT}

Our deepest gratitude goes to Chancellor of Palembang PGRI University, Director of the Postgraduate Program of PGRI Palembang University and the Education Management Study Program of PGRI Palembang University, who have supported us in doing this extraordinary thing. This project is funded independently. We also want to thank our Education Management friends who helped us a lot in a short time frame to complete this project.

\section{REFERENCES}

[1] Djamarah, S. B. (2000). Psikologi Belajar [Psychology of Learning]. Jakarta: Rineka Cipta.

[2] Rosyid, M., Mustajab., \& Abdullah, A. R. (2019). Prestasi Belajar [Learning achievement]. Malang: Literasi Nusantara.

[3] Sardiman. (2016). Interaksi dan Motivasi Belajar Mengajar [Teaching and Learning Interaction and Motivation]. Jakarta: Raja Grafindo Persada

[4] Majid, A. (2014). Strategi Pembelajaran [Learning strategies]. Bandung: PT. Remaja Rosdakarya.

[5] Widiarti, E. (2018). Pengaruh Motivasi Belajar dan Kesiapan Belajar Siswa terhadap Hasil Belajar Mata Pelajaran Ekonomi Siswa Kelas X Ilmu-ilmu Sosial di SMA Negeri 2 Banguntapan, Bantul [The Effect of Learning Motivation and Student Readiness on Learning Outcomes of Class
$X$ Student Economics in Social Sciences at SMA Negeri 2 Banguntapan, Bantul]. Skripsi. Yokyakarta: Fakultas Ekonomi Universitas Negeri Yogyakarta.

[6] Daud, F. (2012). Pengaruh Kecerdasan Emosional (EQ) dan Motivasi Belajar terhadap Hasil Belajar Biologi Siswa SMA 3 Negeri Kota Palopo [The Influence of Emotional Intelligence (EQ) and Learning Motivation on Biology Learning Outcomes of Palopo City 3 Public Senior High School Students]. Vol.9. No 12.

[7] Dimyati \& Mudjiono. (2006). Belajar dan Pembelajaran [Learning and Learning]. Jakarta: Rineka Cipta.

[8] Nugrahadi. E. W., \& Rizki, A. (2018). Pengaruh Kecerdasan Emosional dan Motivasi Belajar terhadap Prestasi Belajar Ekonomi Siswa Kelas X IIS SMA Negeri 1 Raya [The Influence of Emotional Intelligence and Learning Motivation on the Learning Achievement of Class X IIS Students of SMA Negeri 1 Raya]. Jurnal Ekonomi Pendidikan. Vol. 8, No. 6.e-ISSN 2614 - 2295.

[9] Goleman, D. (2000). Emotional Intelegence [Emotional Intelligence]. Jakarta: PT. Gramedia Pustaka Utama.

[10] Ghozali, I. (2006). Aplikasi Analisis Multivariate [Multivariate Analysis Application]. Semarang: Universitas Dipenegoro. 